\title{
Taiwanese Graduate Students' Voices on Language Anxiety over Writing Academic Papers
}

\author{
Yi-Wen Huang \\ University of New Mexico-Gallup, USA
}

\begin{abstract}
This study examined Taiwanese graduate students' language anxiety over writing academic papers utilizing an adapted version of the FLCAS and in-depth individual interviews. The results suggested that the majority of these ten Taiwanese graduate students have experienced high anxiety over writing academic papers. The anxiety they experience over writing stems primarily from grammatical errors, using Chinese English, lacking adequate vocabulary or misuse of English vocabulary, lack of personal opinions, and not understanding the instructions for assignments.
\end{abstract}

Index Terms - Chinese English, grammatical errors, language anxiety, instructions for assignment, personal opinion, Taiwanese student, vocabulary, writing anxiety

\section{INTRODUCTION}

International students studying abroad are expected to turn in academic papers in the majority of their classes. Writing becomes an important part of a foreign student's life, and his/her voices on this issue should be recorded in order to understand his/her anxiety related to writing academic papers while studying in a foreign country. Very few studies in the past captured students' voices on anxiety over writing academic papers (e.g. Kurt \& Atay, 2007) using qualitative methods, especially in relation to international students studying abroad in pursuit of graduate degrees.

Scholars in the field of L1 and L2 writing anxiety/apprehension examined the relationship between writing anxiety/apprehension and many factors were found to have been associated with writing anxiety (e.g., essay type, selfconfidence in writing, self-perception, writing competency, language intensity, writer's block, writing process, teachers' mixed comments, teachers focusing too much on grammar, fear of being evaluated or judged, peer feedback, free reading, leisure writing, academic procrastination from fear of failure and task aversiveness, gender, GPA, etc.) (e.g. Cheng, 2004; Daly \& Miller, 1975; Daly, 1978; Faigley, Daly, \& Witte, 1981; Kurt \& Atay, 2007; Lee \& Krashen, 2002; Lee, 2005; Leki, 1999; Martinez, Kock, \& Cass, 2011; Onwuegbuzie, 1999; Onwuegbuzie \& Collins, 2001; Tsai \& Cheng, 2009), and have found that writing anxiety to be related to writing performance (e.g., Faigley, Daly, \& Witte, 1981; Lee, 2005; Tsai \& Cheng, 2009) or grades in composition classes (Lee \& Krashen, 2002). However, the results are not consistent, and the participants in the previous studies were native speakers of English, ESL, a mix of these two categories, or EFL students, and the studies were set at different educational levels such as college, master's level, or K12.

Based on previous studies (e.g., Daly, 1978; Faigley, Daly, \& Witte, 1981), students' writing- related skills, language intensity, sentence structures, paper length, essay types, or writing performance were found to be associated negatively with writing anxiety. Also, teachers' unclear feedback was also found to be associated with writing anxiety (Leki, 1999). In more recent studies, scholars pointed out that undergraduate students' free reading (Lee, 2005) or leisure writing and self-confidence in literacy (Martinez, Kock, \& Cass, 2011) were found to be associated with writing anxiety.

Based on Faigley, Daly, and Witte's article (1981) published in the Journal of Educational Research, Reeves (1997) defined the term, writing apprehension, as "the tendency to experience a high degree of anxiety when asked to write, resulting in an approach-avoidance conflictive state which manifests itself in one's behaviors, attitudes, and written products" (p. 38). Lee (2005) wrote that according to Daly and Miller (1975), writing apprehension is most likely developed through "negative past experience, especially from teachers' low expectations, evaluations, and excessive error correction" (p. 335).

Onwuegbuzie (1999) summarized a series of studies, and pointed out the use of divergent terminology. Onwuegbuzie (1999) stated that what Daly (1978) termed writing apprehension is referred to as writing anxiety by Thompson (1983), as composition anxiety by Onwuegbuzie (1997), or as writer's block by Rose (1984). However, according to Rose (1984), writer's block and writing apprehension are different. In Rose's definition, writer's block is "broader and subsumes writing apprehension as a possible cause or reaction to blocking" (Rose, 1984, p. 4).

L1 or L2 students' self-perceived ability in writing or in scholastic ability or creativity were found to be associated with writing anxiety but do not suggest a causal relationship but instead a bidirectional or multidimentional construct. Pappamihiel (2002) utilized both qualitative and quantitative methods-Pappamihiel's (2002) English Language Anxiety Scale and focus groups - in order to examine language anxiety in both ESL and mainstream classes. In this study, Pappamihiel (2002) applied both Pekrun's (1992) Expectancy-Value Theory of Anxiety (EVTA) and Bandura's (1991) theory of self-efficacy as models to construct the English Language Anxiety Scale (ELAS). The participants in 
this study included 178 Mexican-born middle school students, grades 6-8, enrolled in an ESL program in Texas. The results of her study suggested that the ELL students' self-perceived skills in reading and writing in English had much to do with the students' anxiety. Those participants who believed that they had high ability in English reading and writing in the mainstream classes had lower levels of language anxiety than those who believed that their reading and writing skills were poor (Pappamihiel, 2002).

Onwuegbuzie (1999) suggested that graduate students' perceived scholastic competence and perceived creativity are interrelated with writing apprehension. Students who perceived of themselves as exhibiting low levels of scholastic competence and creativity tended to experience higher anxiety about writing. Onwuegbuzie (1999) concluded that students' self-perceived scholastic ability and self-perceived creativity and writing apprehension are associated bidirectionally, self-perception and writing apprehension affect each other, and the findings do not suggest "casual patterns among the variables" (p. 1038).

Martinez, Kock, and Cass (2011) conducted a quantitative study on undergraduate students' gender, GPA, attitudes toward leisure writing, writing anxiety, and writing self-efficacy. The results of Martinez et al.'s (2011) study suggested that participants who experience lower writing anxiety are male, have higher GPAs and writing self-efficacy than those with higher writing anxiety (p. 356). Attitudes toward leisure writing are positively related to writing self-efficacy (p. 357); however, it is unclear whether higher levels of self-efficacy reduce levels of writing anxiety or the other way around (p. 357). These authors viewed writing anxiety as a "multidimensional construct" (p. 358).

Daly and Miller (1975) associated WA with writing performance (language intensity). Daly and Miller's study on the relationship between writing apprehension and language intensity, based on a theory developed by Burgoon, Jones, and Stewart as cited in Daly and Miller (1975), found that higher writing apprehensive students utilize less intense language than lower ones. Their subjects were undergraduate English native-language students.

Daly (1978) conducted a quantitative study on undergraduate students in a required basic composition course utilizing two instruments: one, a writing apprehension questionnaire, and the other, a writing competency (skill) test which represented three general areas: "mechanics, grammar, and larger elements involved in composition" (p. 11). The results suggested that students who experienced low levels of writing apprehension performed better than those who experienced high levels of writing apprehension on the writing competency test.

As noted, based on previous literature, WA is related to writing-related skills, and moreover, to writing performance. Faigley, Daly, and Witte (1981) conducted research on the relationships between undergraduate students' writing apprehension and writing competency, and moreover, the students' writing apprehension and writing performance. The results suggested that students who have experienced high apprehension in writing will not score well on writing competency (writing-related skills) tests; these students tend to write fewer subordinate clauses, fewer final non-restrictive modifiers and shorter sentences in narrative/descriptive essays. Also, Faigley et al. (1981) emphasized that there is no casual relationship assumed, and writing apprehension's relationship to performance and competence is mostly likely bidirectional. In other words, they indicated that both competency and performance reinforce apprehension or the other way around.

Lee (2005) conducted a quantitative study on Taiwanese undergraduate students' writing in English and its relationships to various factors (i.e., free reading, free writing, writer's block, writing apprehension, and attitudes toward reading and writing instruction). She offered a number of conclusions: that neither WA nor WB is related to students' writing performance; that free voluntary reading is negatively associated with WA and WB and positively related to writing performance; that self-perceived WA is related to aspects of the composing process (e.g., "frequency of blocking, premature editing, poor planning and interpretive strategies") (p. 344) and to negative attitudes toward writing, based on being negatively evaluated or judged by others - negative past experiences in writing; and that attitudes toward reading and writing instruction failed to significantly predict WA, WB and writing performance. Surprisingly, Lee (2005) found that frequency of writing does not have a significant relationship with WA, WB, or writing performance. She found that free reading leads to more free writing and better quality of writing (performance), but that more writing does not indicate better quality of writing (performance).

Leki (1999) noted that poorly skilled writers might experience FL or L2 writing anxiety; however, highly-skilled writers might also experience this writing anxiety (p. 66). Leki (1999) emphasized that the previous literature on writing anxiety showed that writing anxiety has a negative relation to writing performance, and the fear of being "evaluated or judged on basis of their writing ability" (p. 66), teachers' mixed messages, poor writing skills, and teachers focusing too much on grammar are major sources of writing anxiety. As for educational experiences or teachers' feedback, Leki (1999) emphasized that returning papers marked with red pen tends to makes students anxious about writing, and teachers should balance evaluating on content versus form to reduce students' writing anxiety (p. 67).

Scholars (Price, 1991, p. 106; Gregersen \& Horwitz, 2002, p. 568; Hilleson, 1996) have determined that perfectionism is a possible source of language anxiety. Language anxiety, including writing anxiety, is related to students' belief of insistence upon perfectionism. Foreign/second language students may experience high anxiety in class because they are too concerned about performing without flaws in spite of the fact that this is a natural part of the learning process.

Horwitz (1988) reported that at least forty percent of each group of her subjects, Spanish, French, and German learners, emphasize the goal of speaking the target language with "an excellent accent" (p. 290). She declared that if the 
language learners believe that errors in writing or pronunciation have to be corrected by their instructors, and that they should develop native-like pronunciation in the target language, this may lead to the development of language anxiety. The main source of language anxiety could be the students' beliefs toward the necessity of target language accuracy (Horwitz, Horwitz, \& Cope, 1986; Horwitz, 1988).

To sum up, based on the previous studies, students' self-perceived efficacy in literacy, leisure reading, writing competency, past experiences in writing, instructors' teaching pedagogies, composing process, attitudes toward writing, and perfectionism are all factors associated with writing anxiety. However, the majority of the previous literature concluded these results utilizing quantitative methods. There is a need for research utilizing qualitative methods to obtain foreign students' individual experiences with language anxiety in relation to writing academic papers in order to reduce it.

\section{THE RESEARCH DESIGN}

The present study is best characterized as a qualitative multi-case study. Stake (1995) stated "[t]he real business of case study is particularization, not generalization. We take a particular case and come to know it well, not primarily as to how it is different from others but what it is, what it does" (p. 8). Therefore, qualitative case study is very much personal study. Stake (1995) later emphasized that " $[\mathrm{t}]$ he way the case and the researcher interact is presumed unique and not necessary reproducible for other cases and researchers" (p. 135).

\section{A. Setting}

The study took place at a mid-sized Midwestern university in the United States. According to the university's Office of International Affairs, in recent years, there has been a stable population of over 600 international students registered, which included just over 100 Taiwanese students, and according to the Taiwanese Student Association, about less than a third of whom are graduate students. The university is located in a small town setting which features a relatively homogeneous local population.

\section{B. Participants}

The participants in the study were Taiwanese graduate students who are studying at the American university, who learned English as a foreign language in Taiwan, and who have at least completed high school while still living in Taiwan.

A total of twenty Taiwanese graduate students whose contact information was provided by the president of Taiwanese Student Association were invited to participate in the study. A total of eighteen students (7 male, 11 female) volunteered to fill out the language anxiety questionnaire. Of these, except for the 4 respondents with the lowest scores, fourteen participants ( 4 male, 10 female), whose scores and open-ended questionnaire statements indicated their having experienced some level of language anxiety (from high anxiety to low anxiety), were invited to take part in the interview phase of the study. Of these, eleven ( 2 male, 9 female) accepted the invitation to participate in the interview phase of the study, one (female, slightly anxious) withdrew which left ten ( 2 male, 8 female) to complete the study all the way through. The primary source of data collection for this study was three in-depth individual interviews: the questionnaire was only used for preliminary selection of participants.

\section{Method}

\section{Questionnaire}

The adapted version of the Foreign Language Classroom Anxiety Scale (FLCAS) (Horwitz, Horwitz, \& Cope, 1986) was administered to facilitate the preliminary selection of participants. The FLCAS was adapted to reflect the setting of the study including adding two open-ended statements on students' perspectives of using or writing in English. When the questionnaire and the two open-ended statements indicated that they had experienced some level of anxiety, they were invited to participate in in-depth individual interviews.

2. Demographic Information Sheet

The participants were given the demographic information sheet to fill out and were scheduled for interviews.

3. Three In-depth Individual Interviews

Due to the participants' home culture, it could be difficult for them to express negative experiences in the U.S due to fear of losing face. As a result, in accordance with Swagler and Ellis's (2003) neutralization, it was especially important to inform the participants that negative experiences are also welcome. Personal comments were not provided during the interviews based on Patton's (1990) notion of empathic neutrality. The interview questions are structured, semistructured, and open-ended. Each interview took approximately ninety minutes.

4. Cross-case Analysis

This study utilizes cross-case analysis. Merriam (1988) emphasized that "[e]ach case in a cross-case analysis is first treated as a comprehensive case in and of itself' (p. 154). However, the analysis for a single case study and a multi-case study is "identical" (p. 155). The difference is how the researcher manages the data, and a researcher must find a way to handle all the data without feeling overwhelmed (Merriam, 1988). A researcher doing cross-case analysis "increases the potential for generalizing beyond the particular case" (p. 154). A researcher can "advance to higher levels of analysis" 
(p. 155). At a higher level, "patterns can be developed to explain the interrelationship of variables" (Merriam, 1988, p. 155). In this study, patterns were found and coded based on the interview transcripts.

\section{QUESTIONNAIRE RESUlTS}

The scores were calculated by first reverse-scoring the items which need to be reverse-scored and then dividing the total by the total number of items in the questionnaire (33). Among the eighteen participants, only one participant's score was near 4 (likely to be fairly anxious ); six participants' scores were around 3.5 (anxious); five participants' scores were around 3 and below 3.5 (slightly anxious); and six participants' scores were below 3 indicating low anxiety.

\section{A. Open-ended Questionnaire Results}

Here are responses to the open-ended questionnaire items which were added to the questionnaire. All responses in this section were written in English by the participants.

34. The most difficult thing about using English is

There were various responses to this item. (7/18) Seven of the participants cited academic activities or linguistic forms: "writing a class paper," "writing a dissertation," "idioms," "academic vocabulary using," or "preposition."

35. When I write a paper in English, I usually feel

(7/18) Seven of the participants responded with terms implying a troubled state: "panic," "stressed," "not confident and nervous," "difficult," "stressful and suffering especially in academic paper," or "cautious and careful." In contrast, (7/18) seven of the participants reported they feel "comfortable," "that's not a big deal," "at ease," or "easy" when they write a paper in English.

\section{B. Overview of Interview Participants}

Table 1 gives an overview of the demographic information for the ten interview participants, including their academic majors. Their levels of anxiety from high to low, taken from the questionnaire results, are listed here.

TABLE 1.

INTERVIEW PARTICIPANTS' DEMOGRAPHIC INFORMATION

\begin{tabular}{|l|l|l|l|l|}
\hline Participant & Anxiety & Age & Major & Occupation in Taiwan \\
\hline Ms. A & strongly anxious & 34 & English & college-level English Instructor \\
\hline Mr. B & slightly high & 43 & English & college-level English Instructor \\
\hline Ms. C & moderately anxious & 25 & Business & assistant \\
\hline Ms. D & moderately anxious & 30 & Sports Management & none \\
\hline Ms. E & moderately anxious & 24 & Business & none \\
\hline Ms. F & moderately anxious & 35 & English & English teacher \\
\hline Ms. G & slightly anxious & 25 & English & none \\
\hline Mr. H & slightly anxious & 32 & Business & none \\
\hline Ms. I & slightly anxious & 35 & English & college-level English Instructor \\
\hline Ms. J & not very anxious & 26 & English & none \\
\hline
\end{tabular}

Table 2 shows the academic study program of the students, years studying English, their self-rated English proficiency, and their length of residence in the U.S.

TABLE 2.

ACADEMIC STUdy PROGRAM, SELF- RATEd ENGLISH PROFICIENCY, AND LENGTH OF RESIDENCE IN THE U.S.

\begin{tabular}{|l|l|l|l|l|}
\hline Participant & Program & English & Self-rated English proficiency & Residence \\
\hline Ms. A & Ph.D. & 18.5 years & intermediate & 10 months \\
\hline Mr. B & Ph.D. & 30 years & very good & 4 years \\
\hline Ms. C & MA & 6 years & poor & 1 year \& 6 months \\
\hline Ms. D & MA & $5-6$ years & intermediate & 11 months \\
\hline Ms. E & MA & 12 years & fair & 1 year \\
\hline Ms. F & Ph.D. & 10 years & very good & 10 years \\
\hline Ms. G & Ph.D. & 12 years & very good & years \\
\hline Mr. H & MA & 6 years & fair & 2 years \& 6 months \\
\hline Ms. I & Ph.D. & 12 years & very good & 4 years \\
\hline Ms. J & Ph.D. & 10 years & intermediate & \\
\hline
\end{tabular}

\section{INTERVIEW RESULTS}

The interviews were conducted in Mandarin Chinese. The symbol (E) after a word signifies that the participant spoke an English word instead of Chinese. The following are the common themes analyzed from these three in-depth individual interview transcripts:

1.Chinese English, 2. vocabulary, 3. grammar, 4. lack of personal opinion, 5. organization, 6. not understanding the instructions for assignments, and 7. native vs. non-native English issues in writing.

\section{A. Chinese English}


(4/10) Four of the participants claimed that one of the problems they have experienced when writing papers is their unconscious use of Chinese English. For example, for Ms. I, writing is a "real struggle" because of the perceived effect of Chinese translation:

The main problem is writing $(\mathrm{E})$. I feel that writing $(\mathrm{E})$ is a real struggle! This is a huge problem because when I was in Taiwan, my writing was probably Chinese English, which is when I think in Chinese and then translate it into English. ... In the beginning, my [American] professors could not understand what I wrote. I didn't know how to write...

Likewise, Mr. B claimed that he is trying to pursue "natural" and "standard" English that can be understood, not Chinese English; he hopes to reach his own standard when writing in English:

I think that, probably, my writing will never reach American standards. I still feel that I lack ability in writing. My real ability in writing is lower than I thought. Some of what we write is still Chinese English. I still need to overcome this and write in standard American English, more naturally. Ideally, the paper will not look like it was written by a foreigner. I hope that, at least, my writing will be natural and not Chinese English. Otherwise, people will not be able to understand what I write.

These four participants are worried about their Chinese English and hope to be able to write in standard English.

\section{B. Vocabulary}

(4/10) Four of the participants claimed that lack or misuse of vocabulary is another major problem they experience when writing in English. They find that their problems with vocabulary in writing are very difficult to overcome. Mr. B, Mr. H, and Ms. F all claimed that they still experience these problems in their writing. Mr. B claimed "I still need to work hard" on vocabulary. Mr. H experiences "the same" problems in writing as he did in the past, and he feels that writing is "difficult." Besides his problems in writing which stem from Chinese language transfer to English, Mr. B claimed that the misuse of vocabulary is a problem in his writing as well:

I have Americans revise the words. I did not have a correct understanding of how to use the words: I misuse some words, or the words [I use] should not be used here in the paper. Americans don't use the words that way; only we, foreigners, will do so. I need to work hard on this.

Misuse of vocabulary is problem which worries these participants.

Likewise, the misuse of vocabulary and limited vocabulary are the primary problems Mr. $\mathrm{H}$ faces when writing in English, though he also worries about the lack of stylistic variety in his writing: "My feelings towards writing English papers are that writing is difficult. Word usage or vocabulary is difficult because I always write the same kinds of sentences - the only kind I know how to write." He elaborated further on these problems: "From the past to the present, I have always had the same problems in writing" because "my problems in writing are that my vocabulary is not enough and my usage of the vocabulary is wrong." Even though Mr. $\mathrm{H}$ admitted that his writing has improved, he also claimed that "I don't think that my writing will improve much, just being here ten months."

Even Ms. F, who received her bachelor's degree in the U.S. and has resided in the U.S. the longest of all the participants, still claimed that "because English is not our [my] native language, we [I] basically have some problems with vocabulary." The lack or misuse of vocabulary is the major problem of these four participants.

\section{Grammar}

(8/10) Noting that eight of the participants claimed to consult Writing Center tutors often for grammatical corrections, it is safe to conclude that they are most anxious about grammatical errors in English academic writing, although only a few revealed grammatical problems as a major problem in writing. Three of the participants claimed that grammar is another of the primary problems they experienced when writing academic papers in English. For example, for Ms. D, grammar is a "tremendous problem." It makes her feel "insecure" and "very nervous" if she does not go to the Writing Center to have her grammar checked. Mr. H did cite grammar problems specifically. Ms. D experienced especially strong anxiety about writing. She said she was "very nervous" about writing because "first, I had never written an English paper before, and second, my grammar is a tremendous problem." Moreover, she confided that "I feel insecure if I don't go to the writing center! Probably, my grammar is really a problem. I need to practice grammar more. I just don't feel secure. ... Probably, my personal standards are higher than others'!"

Again, even after residing in the U.S. for over ten years, Ms. F claimed that "after I finish writing my paper, I will ask my [American] friend to check because there probably are some grammatical mistakes." Though she spoke succinctly, her facial expression while saying this seemed to express considerable anxiety and loss of face.

\section{Lack of Personal Opinions}

(3/10) Three of the participants felt that a lack of opinions of their own is one of the major problems they face when writing in English; on a closely related note, they expressed worry over the need to think critically or offer original ideas in their writing. Mr. B claimed that "I think that my writing still has a long way to go. I know that it is unrealistic to compare mine to a native speaker because I can never reach that." He claimed that he uses too many quotes, and he seldom develops his own opinion in his paper. As a result, in his paper, he merely manages other authors' ideas: 
My problem is that I usually use more quotes than my own ideas. When I manage their quotes, I will have different opinions. However, I hardly ever express my own personal ideas in my writing. I usually [just] manage others' articles in my academic writing.

Like Mr. B, Ms. I claimed that she was unable to express her thoughts in writing especially the first time she studied in a Master's program in the U.S.: "I was unable to express my thoughts. ... It took me a long time to clearly articulate my ideas." Now working on her Ph.D., she felt that this problem has improved but added the modifier, "a little bit."

On the same note, Ms. C described writing paper as "difficult" because "I hardly [ever] have my own ideas." She elaborated further: "I usually can only write what I learn in class or what I studied before. My professors usually want to read something creative. ... However, I usually don't form my own opinions. My ideas all come from what my teachers tell me." Originality or creativity seems to be a relevant issue among these students.

Addressing the need for original or critical ideas, Ms. G noted that "writing was a struggle for me because I didn't know what direction I should write because we all copied the content from the internet in Taiwan. ... But here the teachers required you to use critical thinking, to write directly to the point, etc." Furthermore, she stressed that "Taiwanese education [English classes] focuses on grammar ... or we were asked to write summaries. Because I was not required to write my ideas, argumentation, or thesis statements, I didn't know how to write when I first came here to study." It seems that the Taiwanese system of English education requires more grammar than originality, and moreover Chinese rhetorical conventions, such as a lack of thesis statements and citations of academic sources, might be a source that affects these participants' English academic writing.

\section{E. Organization}

$(2 / 10)$ On a related theme, two of the participants revealed that they have both experienced strong levels of anxiety associated with the organization of their writing. They claimed to still not be able to overcome this problem. The idioms they use to describe this problem, such as "the most painful" "the most difficult," and "struggle" (Ms. A) and "very annoyed," and "very difficult" (Ms. G).

After taking two semesters of doctoral courses in America, Ms. A still feels "pained" writing in English: "Now, writing is difficult, very difficult." Ms. A's difficulties in English academic writing feature quite intense concerns about content and organization:

After reading the related articles, the difficulties are how to cite them in an organized manner and how to integrate information from the articles into my own writing. ... It usually takes me a long time to find a topic for my paper, and then I check out the related articles. After finishing reading them, the most difficult and painful part is how to write them down, how to include them in the paper, and how to organize them. It is a struggle. My writing process is like my brain is turning and turning to squeeze the brain fluid out. It takes a long time to write. I write slowly, a little bit at a time. Writing is a very bad experience for me.

Ms. G has experienced the same problem in academic writing as Ms. A. She described her experience in writing:

Every time, when I talk about writing, I feel very annoyed because the problem I have now in my writing is the inability to organize the ideas! Because I don't just write, I also have to do research to find information. However, when I have a topic to write about, I usually have a ton of literature which needs to be cleaned up. Organizing the ideas in writing is very difficult for me. The thoughts do not flow, which means the ideas are not organized. For example, there might be a lot of literature, but the problem is, "how should I write about this first, that next, and then connect them and tie them together?"

Both Ms. A and Ms. G revealed the struggle they experienced organizing ideas from previous literature. They both have problems tying and connecting the literature together. It has something to do with comprehending and analyzing the relevance of the literature and then organizing the ideas in a logical sequence.

\section{F. Not Understanding the Instructions for Assignments}

(4/10) Four of the participants revealed that they have experienced anxiety associated with not understanding the instructions for their assignments. They used such expressions as feeling "pained" (Ms. F) and "the pain of studying here" (Ms. A).

Ms. E asked "why do I spend so much time writing a paper because I am not sure what the professor wants me to write . . . ?" Also, Ms. F claimed that she spends a great deal of time writing a paper, and "I feel pained if I am not sure what the professor wants me to write." Not understanding the assignment is another source of the anxiety these students are experiencing.

Ms. G claimed to have experienced similar uncertainty, citing times when she "didn't know what my [her] teacher's requirement was." Ms. A spoke of the pain she experienced studying in her doctoral program: trying to meet the requirement of handing in a good paper. But she seemed to agree, claiming that her professors do not teach her how to write. Her phrasing is remarkably close to that of Ms. G: "The pain of studying here is that there is no one teaching you [me] how to write, but in each class, the professors require you [me] to hand in a good product." Ms. E, Ms. F, and Ms. $\mathrm{G}$ all claimed that their anxiety is associated with not understanding the assignment and their professors' requirements. Ms. G also mentioned that no one teaches her how to write, but at the doctoral level, students are expected to be familiar with the standard form of academic writing. 


\section{G. Native vs. Non-Native English Issues in Writing}

(2/10) Two of the participants have experienced a high level of anxiety associated with their perceived professors' attitudes toward non-native speakers of English. They complained about their professors' inconsistent attitudes towards what they describe as "World English." One described this as "the most difficult issue" (Ms. A), and another complained of professors "forcing us to be native-like" (Ms. G).

Ms. A expressed frustration and resentment about some of her experiences studying in the U.S. She referred to one particular comment from a professor who cautioned her against "ESL issues in [her] writing." He/she wrote, "you should pay attention to ESL issues." She had a strong reaction to this comment; in fact, she seemed to feel that this kind of feedback was automatically doled out to non-native speakers regardless of the quality of their writing:

I should not be stuck in this problem. I have never received a paper on which the professors' comments are "excellent." My papers are all checked by a native speaker. You never receive an excellent comment because he/she knows that you are not American. This is the only thing he/she obviously knows. I don't really think that what I write is Chinese English, but you can see that what I write is not written by an American. This makes me feel hurt.

She elaborated further on this experience:

The issue of native vs. non-native is what frustrated me the most about studying here! To have to express oneself in a native-like manner is the most difficult. They [American professors] should accept us the way we are.

She hopes that her American professors can accept her as the way she is - as a non-native speaker.

This unpleasant experience made her self-conscious and therefore very anxious about her English writing, transferring from her native language, Chinese. But, later, she claimed that she should be confident in "Chinese English": "I pursue standard English, but I feel I should not look down on Chinese English." In any case, she felt that her professors were inconsistent, in claiming, on the one hand, to accept "World Englishes" while in the meantime expecting native-level performance from international students:

They preach that people should not be impatient when dealing with non-native speakers. They teach concepts of world English. ... In practice, however, they do distinguish between native and non-native speakers. Some professors teach you that we should not distinguish between them, but they actually do.

Ms. G has experienced the same source of anxiety. She claimed that

They [American professors] keep preaching to me that I don't need to be native-like [to possess native-level ability] and that it will be impossible for me to be native-like. But, they force us to be native-like. Why do they have to force us to be native-like?

In her frustration, she asked, "So does that mean - that the theories they teach us are not true? They do not act the same way as what they teach us. They do not practice what they preach." These two participants claimed that their professors did not practice what they preached when it came to World Englishes and that they feel because they will never be able to write at native-level fluency, they will not be taken seriously.

In summary, writing obviously arouse high emotional reactions to some of these participants. Most of these ten Taiwanese graduate students claimed to have experienced high level of language anxiety over writing academic papers, and they claimed to be very "worried" about grammatical mistakes, using Chinese English, lacking adequate vocabulary or misuse of vocabulary, lack of personal opinions, and not understanding the instructions for assignments. Especially, eight out of ten claimed to have experienced strong writing anxiety over not being sure whether or not their academic papers have grammatical mistakes. This caused them to experience much discomfort, including sleeplessness or writers' block; one mentioned drinking alcohol with friends to calm her nerves over these problems.

Their language anxiety stemming from writing academic papers conveys strong emotional involvement, as they refer to "the pain of studying here," or claim that "grammar is a tremendous problem," or "writing is a very bad experience," or profess themselves to be "insecure" or "very nervous."

Conflicts between Taiwanese and American classroom practices include lack of personal opinions in academic writing which three of the participants claimed has affected their academic English writing. Also, they claimed that, in Taiwan's educational system, grammar is the only focus in writing classes, and they were never before required to write reflections, personal opinions, or critical ideas in their English papers.

Two of the participants, Ms. A and Ms. G, both reported that, based on theories of World Englishes, some of their American professors preached to not overly emphasize native-like proficiency for non-native speakers. Yet at the same time, the participants felt the pressure to write native-like because they perceived that their professors indeed distinguish between native vs. non-native English writing proficiency, and they felt the professors look down on or cannot accept them as second-language speakers. They feel "hurt" or "frustrated" by their perceived American professors' attitudes. This causes them to be very anxious over their English writing proficiency. Their level of writing anxiety is very high due to perceived expectations of their American professors: native-like English proficiency.

\section{DiscusSION}

The majority of the participants are worried about grammatical errors in the academic writing. Some are worried about Chinese English or not written to the native-level proficiency. This anxiety over making mistakes has been identified in the literature. For instance, Price's (1991), Gregersen and Horwitz's (2002), and Hilleson's (1996) studies all show that language learners' high anxiety can be related to over-concern for performing perfectly without flaws. 
This also brings to mind Horwitz et al.'s (1986) and Horwitz's (1988) studies, which concluded that the primary source of language anxiety is students' belief in the necessity of high levels of target language accuracy. Also, the current study also found that professors' expectations or requirements of native-like ability in English academic writing have intensified their language anxiety over writing.

As for these participants' anxiety over not understanding the instructions for assignments, instructors can discuss assignments with students one-on-one during class sessions or arrange students to discuss assignments in small groups in order to clarify assignments.

Lack of personal opinions was found to be an important causal factor. This factor is related to Chinese rhetorical conventions and the Taiwanese educational system, respectively. Instructors need to explicitly teach foreign students, especially Chinese students, English rhetorical patterns such as argumentative or research papers in order to help familiarize them with the genre conventions and assign students in groups to discuss or evaluate strengths and limitations from the academic readings to implement foreign students' critical thinking skills.

Two participants claimed that their professors' negative comments/written feedback on their English academic papers - the respondents' perceptions that their professors look down on or cannot accept them as non-native speakers - have enormously influenced their anxiety in their writing. This finding recalls MacIntyre and Gardner's (1991) claim that teachers should encourage language learners more and enhance their self-confidence in the target language in order to reduce their language anxiety.

One participant specifically cited one of her American professor's comment on her academic paper regarding "ESL issues" which he/she wrote on her returned paper with no other feedback. Although the professor may have written this remark casually, thinking the writer would simply take it in stride, the comment ultimately made her very upset and worried about native vs. non-native speaker issues. Her professor's comment caused her to be very conscious of her status as a non-native speaker or writer. Again, this finding can be related to Leki's (1999) finding that writing anxiety is associated with learner's educational experiences, in particular to the fear of "[being] judged or evaluated" on their writing ability.

As for these participants' anxiety over organization of academic papers, instructors can request students to attach outlines when turning in the final versions or bring outlines to class and assign students to discuss their outlines together to help better organize their ideas for the assignment.

\section{IMPLICATIONS}

The majority of these Taiwanese graduate students have experienced a high level of anxiety over grammatical errors which are associated with the anxiety over American professors' expectation of native proficiency, their Chinese English, or their misuse of vocabulary. They are facing the difficulties of reaching the standard or expectations in the academic discourse community where their American professors are the audience of their academic papers and where the dominant variety/ inner-circle variety is the norm. However, international students' use of English forms which are influenced by their mother tongues is inevitable, leading Acar (2007) to state

It is argued that while the inner-circle, native-speaker standard English should still serve as the pedagogical model in this circle, there must be allowance for pragmatic and discourse variations in these English users' speech since these levels of language are strongly shaped by the cultural contexts of these speakers. (p. 51)

This concept might lead instructors to reconsider their evaluation strategies for foreign students' English academic papers.

When assessing foreign students' writing, instructors could apply Kasper and Petrello's (1998) "nonjudgmental instructional approach" (p. 184) which emphasized "the fluent and clear expression of ideas over correctness of form" (p. 181). Canagarajah (2006) wrote that instructors "should perceive 'errors' as the learner's active negotiation and exploration of choices and possibilities" (p. 593). Hornberger (2004) stated that when evaluating foreign or second language learners' work, educators should always take into account "an ungrammatical expression of accurate content, or a grammatically correct expression of inaccurate content, may be just as much a sign of learning as a grammatically correct expression of accurate content" (p. 166). Instructors teaching at universities in the inner circle countries (i.e., USA, Canada, UK, or Australia) may consider focusing on foreign students' content and take into account the influence of their native languages in their academic writing.

For these participants studying at an American university who are very anxious about grammatical errors, Chinese English, or native-like proficiency, their professors are the main audience. Canagarajah (2006) emphasized that instructors must teach students to "negotiate grammar for their rhetorical purposes" (p. 610) such as purpose, context, and audience.

On the same note, some of the participants reported feeling anxious about not understanding assignment instructions. Horner (1994) stated that "[i]n reinforcing the students' sense of being in a position to negotiate, we enable them to see writing as a negotiating process of bargaining as to what might count as what, to whom, for what purposes, under what circumstances" (pp. 46-47). Baker (2009) emphasized that "for learners of English as a lingua franca, the ability to negotiate, mediate, and adapt to emerging communicative practices is at least as important as systematic knowledge of languages and their specific relationships to other cultures" (p. 588). For participants who reported problems with rhetorical conventions, such as thesis statements and citations of academic sources, Matsuda and Matsuda (2010) 
suggested teaching the dominant and non-dominant forms and functions to students and the boundary between what works and what does not in specific communicative contexts, and strategies of negotiating with readers by applying features such as quotation marks, endnotes, etc. to show credibility. Also, Canagarajah (2006) recommended that "we should teach communicative strategies - i.e., creative ways to negotiate the norms relevant in diverse contexts" (p. 593). Students, especially foreign students, need to be taught these strategies to negotiate in the academic community which essentially constitutes communicative competence.

In this study these ten Taiwanese graduate students are facing writing anxiety in the academic discourse community which the mainstream standard or inner-circle variety of English might be expected of them by their American professors who are the audience, the readers, and the context is the U.S. classroom or the academic community in general. Graduate students are expected to present their works at academic conferences and publish their academic papers in research journals where the mainstream or traditional dominant norm of English is the norm. Admittedly, it is difficult to preach World Englishes, while at the same time expecting the norm for the international graduate students to be the inner-circle variety.

Based on the findings of this current study, instructors need to be cautious when providing feedback on students' academic papers because this might increase the level of writing anxiety. Also, foreign students should be encouraged to engage in dialogue with American professors using communicative strategies to negotiate with their instructors after receiving their graded returned papers by asking questions about the professors' feedback in the papers. By negotiating the meanings of professors' feedback, foreign students gain more opportunities to improve their writing and understanding of the academic language in the studies, and in doing so, their levels of anxiety over writing academic papers could be lowered. Also, during this process foreign students empower themselves as active learners and writers in dynamic academic discourses with their American professors.

\section{LiMITATIONS OF THE STUDY}

The findings of this study lack generalization because the primary sources of data collection came from qualitative methods and the number of the participants is small. Also, each participant in the study was investigated as a unique individual, so the findings of the study lack generalization. Future studies of this nature will be needed before it can be known whether the findings of this study are similar to what emerges from studying the same or other populations in similar contexts.

\section{RECOMMENDATIONS FOR FUTURE RESEARCH}

It is necessary to urge more qualitative studies on international students' personal experiences of writing anxiety. Also, foreign students' anxiety over writing which stems from rhetorical conventions should be investigated, so educators can understand this anxiety and are able to adjust their teaching pedagogies and provide students coping strategies.

\section{REFERENCES}

[1] Acar, A. (2007, December). Standards and competence in English as an international language pedagogy. Asian EFL Journal, 9(4), 39-53.

[2] Bandura, A. (1991). Self-efficacy conception of anxiety. In R. Schwarzer, \& R.A. Wicklund (Eds.). Anxiety and self-focused attention (pp. 89-110). New York: Harwood Academic Publishers.

[3] Baker, W. (2009, December). The cultures of English as a lingua franca, TESOL Quarterly, 43(4), 567-592.

[4] Canagarajah, A. S. (2006, June). The place of world Englishes in composition: Pluralization continued, College Composition and Communication, 57(4), 586-619.

[5] Cheng, Y. (2004). A measure of second language writing anxiety: Scale development and preliminary validation, Journal of Second Language Writing, 13, 313-335.

[6] Daly, J. A. (1978, Sep-Oct). Writing apprehension and writing competency, Journal of Educational Research, 72(1), 10-14.

[7] Daly, J. A., \& Miller, M. D. (1975). Apprehension of writing as predictor of message intensity, The Journal of Psychology, 89, 175-177.

[8] Faigley, L., Daly, J. A., Witte, S. P. (September/ October, 1981). The role of writing apprehension in writing performance and competence, Journal of Educational Research, 75(1), 16-21.

[9] Gregersen, T., \& Horwitz, E. K. (2002). Language learning and perfectionism: Anxious and non-anxious language learners' reactions to their own oral performance. The Modern Language Journal, 86(4), 562-270.

[10] Hilleson, M. (1996). "I want to talk with them, but I don't want them to hear": An introspective study of second language anxiety in an English-medium school. In K. M. Bailey, \& D. Nunan (Eds.).(1996). Voices from the language classroom: Qualitative research in second language education (pp. 248-275).Cambridge: Cambridge University Press.

[11] Hornberger, N. H. (2004). The continua of biliteracy and the bilingual educator: Educational linguistics in practice. Bilingual Education and Bilingualism, 7 (2\&3), 155-171.

[12] Horner, B. (1994, February). Mapping errors and expectations for basic writing: From the "frontier field" to "border country", English Education, 26(1), 29-51.

[13] Horwitz, E. K. (1988). The beliefs about language learning of beginning university foreign language students. The Modern Language Journal, 72(3), 283-294. 
[14] Horwitz, E, K., Horwitz, M. B., \& Cope, J. A. (1986). Foreign language classroom anxiety. In E. K. Horwitz, \& D. J. Young (Eds.) (1991). Language anxiety: From theory and research to classroom implications (pp. 27-36). Englewood Cliffs, NJ: Prentice-Hill.

[15] Kasper L. F., \& Petrello, B. A. (1998). Responding to ESL student writing: The value of a nonjudgmental approach, Community Review, 16, 178-185.

[16] Kurt, G., \& Atay, D. (2007). The effects of peer feedback on the writing anxiety of prospective Turkish teachers of EFL, Journal of Theory and Practice in Education, 3(1), 12-23.

[17] Lee, S. (2005, June). Facilitating and inhibiting factors in English as a foreign language writing performance: A model testing with structural equation modeling. Language Learning, 55(2), 335-374.

[18] Lee, S., \& Krashen, S. (December 2002). Predictors of success in writing in English as a Foreign language: Reading, revision behavior, apprehension, and writing, College Student Journal, 36(4), 532-544.

[19] Leki, I. (1999). Techniques for reducing second language writing anxiety. In D. J. Young (Ed.). Affect in foreign language and second language learning: A practical guide to creating a low-anxiety classroom atmosphere (pp. 64-88). USA: McGraw-Hill

[20] MacIntyre, P., \& Gardner, R. C. (1991). Investigating language class anxiety using the focused essay technique. The Modern Language Journal, 75(3), 296-304.

[21] Martinez, C. T., Kock, N., \& Cass, J. (2011, February). Pain and pleasure in short essay writing: Factors predicting university students' writing anxiety and writing self-efficacy, Journal of Adolescent \& Adult Literacy, 54(5), 351-360.

[22] Matsuda, A, \& Matsuda, P. K. (2010, June). World Englishes and the teaching of writing, TESOL Quarterly, 44(2), $369-374$.

[23] Merriam, S. B. (1988). Case study research in education: A qualitative approach. California: Jossey-Bass.

[24] Onwuegbuzie, A. J. (1997). Writing a research proposal: The role of library anxiety, statistics anxiety, and composition anxiety. Library and Information Science Research, 19, 5-33.

[25] Onwuegbuzie, A. J. (1999). Writing apprehension among graduate students: Its relationship to self-perceptions. Psychological Reports, 84, 1034-1039.

[26] Onwuegbuzie, A. J., \& Collins, K. M.T. (2001). Writing apprehension and academic procrastination among graduate students, Perceptual Motor Skills, 92, 560-562.

[27] Pappamihiel, N.E. (2002, February). English as a second language students and English language anxiety: Issues in the mainstream classroom. Research In The Teaching Of English, 36, 327-355.

[28] Patton, M. Q. (1990). Qualitative evaluation and research methods ( $2^{\text {nd }}$ ed.). Newbury Park, CA: Sage.

[29] Pekrun, R. (1992). Expectancy-value theory of anxiety: Overview and implications, In D. Forgays \& T. Sosnowski (Eds.) (1992). Anxiety: Recent developments in cognitive, psychological, and health research (pp. 23-39). Washington, DC: Hemisphere.

[30] Price, M. L. (1991). The subjective experience of foreign language anxiety: Interviews with highly anxious students. In E. K. Horwitz, \& D. J. Young (Eds.). Language anxiety: From theory and research to classroom implications (pp. 101-107). Englewood Cliffs, NJ: Prentice-Hill.

[31] Reeves, L. L. (1997, October). Minimizing writing apprehension in the learner-centered classroom. English Journal, 86 (6), 38 46

[32] Rose, M. (1984). Writer's block: The cognitive dimension. Carbondale, IL: Southern Illinois University Press.

[33] Rose, M. (2004). Writing around rules. In S. Reid (2004). Purpose and Process (5th. ed.) (pp. 88-94). Upper Saddle River, NJ: Pearson Education.

[34] Stake, R. E. (1995). The art of case study research. Thousand Oaks, CA: Sage.

[35] Swagler, M. A., \& Ellis, M. V. (2003). Crossing the distance: Adjustment of Taiwanese graduate students in the United States. Journal of Counseling Psychology, 50(4), 420-437.

[36] Thompson, M. (1983). The returning student: Writing anxiety and general anxiety. Teaching English in the Two-year College, $10,35-39$

[37] Tsai, P., \& Cheng, Y. (2009, Fall). The effects of rhetorical task type, English proficiency, and writing anxiety on senior high school students' English writing performance. English Teaching \& Learning, 33(3), 95-131.

Yi-Wen Huang received her Ph.D. in English: Composition \& TESOL from Indiana University of Pennsylvania. She is currently an Assistant Professor of English and Linguistics at the University of New Mexico-Gallup, USA. Her research interests include language anxiety, writing anxiety/apprehension, and Native American literacies. Dr. Huang is a member of the College English Association. 